\title{
Tax Revenue and Public Service Delivery: Evidence From Nigeria
}

\author{
Cordelia Onyinyechi Omodero $^{1} \&$ Kabiru Isa Dandago ${ }^{2}$ \\ ${ }^{1}$ Department of Accounting, College of Management Sciences, Michael Okpara University of Agriculture, Umudike, \\ Abia State, Nigeria \\ ${ }^{2}$ Department of Accounting, Faculty of Management Sciences, Bayero University, Kano-Nigeria \\ Correspondence: Cordelia Onyinyechi Omodero, Department of Accounting, College of Management Sciences, \\ Michael Okpara University of Agriculture, Umudike, Abia State, Nigeria.
}

Received: March 18, 2019

Accepted: April 4, 2019

Online Published: April 10, 2019

doi:10.5430/ijfr.v10n2p82

URL: https://doi.org/10.5430/ijfr.v10n2p82

\begin{abstract}
The paper employs ordinary least squares technique to investigate the impact of tax revenue on public service delivery in Nigeria from 1981 to 2017. The specific objective is to determine the extent to which tax revenue influences service delivery indicators such as education and health care services in the country. The findings reveal that tax revenue impacts positively and significantly on education and health care services. The study therefore recommends among others that the government should exploit all tax revenue sources and use same to maintain the health sector in the country and provide adequate education including skill acquisition and entrepreneurship development programmes for the citizens.
\end{abstract}

Keywords: tax revenue, public service delivery, education, healthcare services

JEL Codes: H2; I1, I2

\section{Introduction}

Tax revenue is an influential instrument of economic transformation and a key player in every economy globally. It is certainly not stationary but sufficiently dynamic to depict all existing and predominant economic realities in a nation. Tax revenue is the most vital and principal tool that boosts and sustains economic growth of a country (Munir \& Sultan, 2016). It affords emerging countries an unwavering and foreseeable economic environment that promotes growth and conveniently funds social and physical infrastructural needs (Takumah, 2014). Taxation is the most important revenue source of the government which helps in provision of public goods and services (Omodero, Okafor, Azubike \& Ekwe, 2016).

The entire essence of tax is to generate revenue that will promote the wellbeing of the citizens in a country with emphasis on stimulating economic growth and development of a nation through the provision of basic facilities for better public services by way of suitable governmental structure, and arrangements. An efficient tax system provides a strong channel to exploit internal revenue sources of a country for proper public service delivery. Public service delivery is the mechanism through which public services are delivered to the public by local, state, or federal governments and these services include provision of public education, health services, street cleaning, sewage and trash disposal (IGI Global, 2018).

The importance of proper public service delivery has led to enactment of relevant laws in many developed and developing countries. For instance, the USA's Government Performance and Results Act (GPRA), Japan's Public Service Act, Uk's Citizens' Charter among others (Frost \& Sullivan, 2012). In conjunction with World Bank, several countries in Africa now make effort to collect Service Delivery Indicators (SDI) which basically focus on education and health care services. The governments of the African countries initiated this move to be able to collect reliable data on service delivery in schools and health facilities. This effort will help decision makers to monitor the service delivery progress over time while citizens will have the yardstick to hold the governments responsible for all public expenditure (Open Government Partnership, 2018).

In Nigeria and some other developing countries, there is increase demand for public services, especially for health, education, housing, water, transport and communication. Nigeria's first Service Delivery Indicators (SDI) survey results on education was released in September 2014 while Hanovia Medical Limited with the backing of the World 
Bank carried out the health surveys (World Bank, 2017). The data gathered were from 2,480 rural and urban health facilities across 12 states which included 2,298 public providers and 182 private facilities, about 12,678 health providers were also measured in absence. The outcomes portrayed the quality of health service delivery seen within the public and private health centers in Nigeria (World Bank, 2017). However, the primary aim of a tax system is to finance public goods and services, promote efficient distribution of resources, reduce income inequality, and to stabilize the economy (Musgrave, 2006). Besides these backdrops, Chigbu, Akujuobi and Appah (2012) argued that apart from generating revenue, a tax system is also used as a fiscal policy tool to influence investment direction and regulate the production and consumption of certain goods and services.

It is worthy to note that collection of taxes by the federal, state and local governments is statutory and it is contained in the second schedule part II of the 1999 constitution of the Federal Republic of Nigeria. The concurrent list is made up of obligations and items under the control of the three tiers of government in Nigeria. By implication, it is a list where the taxing powers of the federal, state, and local governments are explicitly specified. However, it has been observed that Nigerians do not perceive compliance to tax payment as an obligation and part of their civic responsibility due to failure on the part of the government to provide adequate public goods and services. The government equally lacks maintenance culture as the facilities already provided are not maintained, so they feel there is no commensurate benefit to be derived from tax payment compliance. Based on this premise, most individuals and firms practice tax avoidance and evasion which results to reduction in government revenue.

\subsection{Objective of the Study}

The major objective of this study is to determine the effect of tax revenue on public services provided by the government in Nigeria. In line with the two basic Service Delivery Indicators (SDI) under monitoring in Nigeria and other African countries, the study gives primary consideration to education and health care services which are the basic SDI in Nigeria. Therefore, the specific objectives of the study are as follows:

1. To assess the impact of tax revenue on education (EDU) in Nigeria;

2. To establish the influence of tax revenue on health care services (HLT) in Nigeria;

\subsection{Research Hypotheses}

To pursue the above specific objectives of the study, the following null hypotheses have been formulated:

$\mathrm{Ho}_{1}$ : Tax revenue does not have significant impact on education in Nigeria;

$\mathrm{Ho}_{2}$ : Tax revenue does not significantly influence health care services in Nigeria;

\section{Literature Review}

\subsection{Conceptual Review}

\subsubsection{Concept of Taxation}

Taxation is the key to promoting sustainable growth and poverty reduction (Takumah, 2014). The concept of taxation is derived from the submissions of eminent scholars like (Dandago \& Alabede, 2001; Piana, 2003; Anyaduba, 2004; Nzota, 2007; Brautigam, 2008; Appah, 2010) among others. Dandago and Alabede (2001) acquiesced that taxation is an obligatory but non-retributive levy by the government through its agents on the profits, income or consumption of its subjects or citizens, to facilitate government's spending on public goods and services. Piana (2003) opined that taxation is an application of tax rate to a tax base. Anyaduba (2004) described taxation as a fiscal tool the government uses to generate revenue. According to Nzota (2007), taxation is a compulsory payment by the citizens to the government; it is a general obligation on the part of the tax payers; the benefits of tax may not be commensurate with the revenue and the government levies the citizens for the services provided to them. Brautigam (2008) states that if tax system is properly designed it could enhance provision of adequate infrastructures and improve public sector accountability. Appah (2010) submitted that the role of taxation in economic growth achievement is very enormous and Nigeria cannot be left behind.

However, high tax rates results in tax avoidance and evasion (Chokri, Anis, Ali \& Khalil, 2017). Therefore, more taxpayers are likely to defraud or to avoid paying taxes, due to higher taxes demanded by the government. However, lower taxes reduce the likelihood of fraud and tax evasion (Chokri et al., 2017). Engen and Skinner (1992) described five ways taxes might have adverse effect on economic growth. First, higher taxes can discourage investment because firms and individuals pay these taxes from the income that could have been re-invested for business expansion and to enhance economic growth. Second, taxes may reduce growth of labour supply by discouraging work force participation or hours of work, or individuals' ambitions to acquire higher education, skills or training. 
Third, tax policy has the tendency to discourage research and development (R\&D) that could enhance productivity and technological advancement for industries. Fourth, tax policy can influence marginal productivity of capital by diversifying investment from heavily taxed sectors to less taxed sectors with lower overall productivity (Harberger, 1962; 1966). Fifth, heavy taxation on labour supply can distort the efficient use of human capital by discouraging workers from accepting employment in sectors with a heavy tax burden no matter the high social productivity.

Despite the challenges associated with tax revenue collection and its negative influence on an economy, it has been proved to be a good source of government revenue that is absolutely certain in collection. Tax revenue in Nigeria from 1981-2017 are shown in Figure 1 below. The vertical axis depicts the tax revenue in billions of Naira while the horizontal area indicates the time on a yearly basis.

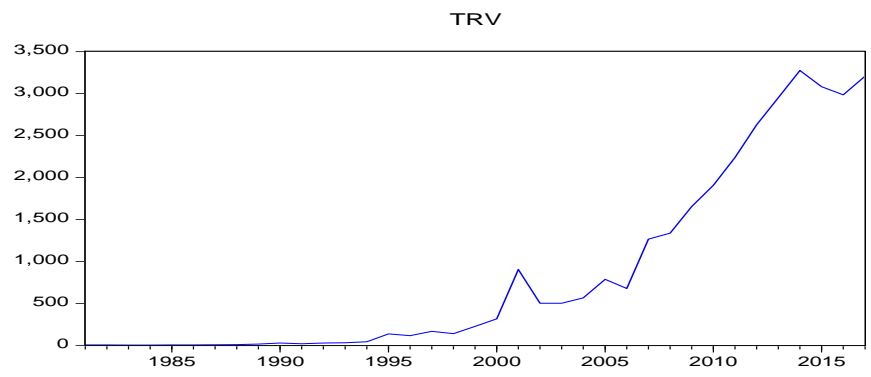

Figure 1. Trend of tax revenue from 1981-2017

Source of Data: CBN Statistical Bulletin, 2017 edition.

Figure 1 shows the flow of revenue from all taxes except petroleum profit tax. The attention given to tax revenue drive by the government in the recent times in Nigeria has led to increase in tax revenue as can be witnessed in 2011 from Figure 1 above. Though there was a little drop between 2014 and 2015, but a sudden rise occurred between 2016 and 2017 thereby given credence to government's effort to exploit tax revenue sources due to the dwindling oil revenue.

\subsubsection{Public Service Delivery Concept}

Public service is a service which is provided by government to people living within its jurisdiction, either directly (through the public sector) or by financing provision of services (McGregor Jr., Campbell, Macy \& Cleveland, 1982). Service delivery is the process of extending basic services like education, healthcare, water, housing, transport and communication where the end users are the public or local people within the country (Ray, 2007). Public service delivery has been perceived as a fundamental function of the modern governments. It evolves as one of the tools available to the governments for developmental goals implementation, and economic growth channels focusing on creating appropriate and conducive environment for economic sectors to perform optimally (Frost \& Sullivan, 2012). This major responsibility propels the government to continually find a better and preferred avenues to deliver services to the people, however, there must be regulations governing public service delivery.

Public service has direct relationship with people's collective agreement shown when leaders are democratically elected to deliver public services to the citizens no matter their income status, physical capabilities and mental alertness (Anderfuhren-Biget, Varone \& Giauque, 2014). The provision of public services such as health care, education, sanitation and criminal justice is a key task of government. The effectiveness of public service delivery depends on the ability of the government to overcome the challenge of not allowing people to participate in finding solution to their public service needs. The delivery of public services in line with citizens' needs rather than the governments' should be the primary aim of every public administration. Therefore, Frost and Sullivan (2012) identified six principles underpinning effective public service delivery. They include: co-creation of service; clear and measurable outcomes; transparent monitoring and evaluation, accountability of public programs; strong policy/program management; rapid and lean transformation.

Public services provide the most common interface between the government and the people that are being governed. People are concerned about public services and expect to have them delivered properly. Adequate public service delivery enhances public trust and confidence in any administration and so its provision by governments depicts care for human welfare and promotes economic growth. Therefore, public services need to be delivered with integrity, 
with special attention to the needs of the citizens, especially the needs of the most vulnerable (Open Government Partnership, 2018). Promoting greater transparency and enabling ordinary citizens to assess the quality, adequacy and effectiveness of basic services to voice their needs and preferences and to become involved in innovation efforts offers an opportunity to enable better use of public funds, and improve service delivery (Ringold, Alaka, Koziol \& Santhosh, 2012).

Education and health care services are the major service delivery indicators (SDI) powered by African governments in collaboration with the World Bank. In Nigeria government's spending on education are depicted on Figure 2 below.

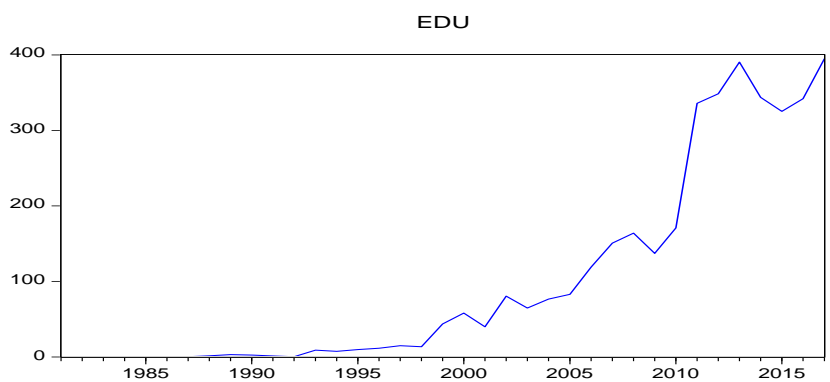

Figure 2. Trend of government expenditure on education from 1981-2017

Source of Data: CBN Statistical Bulletin, 2017 edition.

Figure 2 shows that government spending on education has not been on a steady increase. It rises and falls, due to availability of income and other economic factors affecting government's revenue. The amount of expenditure on education is on the perpendicular axis in Figure 2 while the parallel lane portrays the time frame on an annual basis.

In the same manner, the spending on health care services is shown on Figure 3 below.

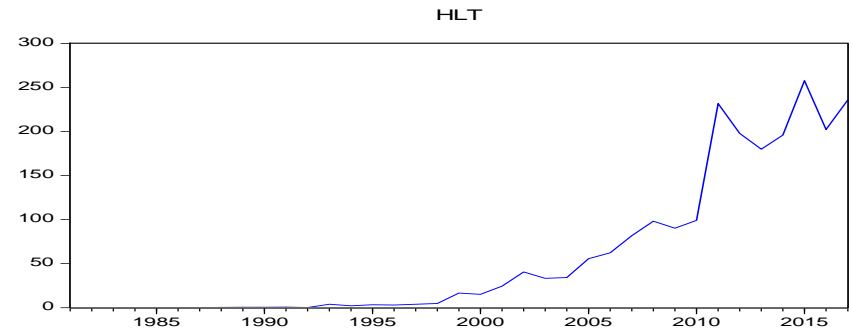

Figure 3. Trend of Government expenditure on health care services from 1981-2017

Source of Data: CBN Statistical Bulletin, 2017 edition

Figure 3 shows government expenditure on health care services form 1981-2017. It appreciates considerably in 2011 and 2015 but declined in 2016. The importance of health care service and education in Nigeria has prompted the government to take into account SDI in collaboration with other African countries. Government emphasis on tax revenue has a fundamental role to play in achieving this objective.

\subsection{Theoretical Framework}

The theory underpinning this study is Benefit Received Theory of taxation pioneered by Wicksell (1896) and Lindahl (1919). The theory focuses on the usefulness of tax revenue in providing public services and supports government at all levels (federal, state and local) to raise revenue from a variety of sources in order to adequately provide public goods and services to the populace. Governments collect taxes from both individuals and companies for the purpose of providing basic amenities such as water, housing, education, health care services, security, transportation and communication among others. The theory assumes an exchange relationship between the tax-payers and the government. The government has the responsibility to provide basic amenities to the public while they reciprocate by paying taxes that are proportionate with the benefits derived (Bhartia, 2009). 
According to Anyanfo (1996), taxes should be levied on the basis of benefits received from the government. The theory emphasizes that individuals and companies should pay taxes based on their ability to pay and proportion of benefits they receive. In other words, individuals and companies that receive higher benefits pay higher taxes. However, this theory has not been fully applied in any circumstance because the government has also failed to measure the benefits received by individuals and firms with the services rendered (Ahuja, 2012).

\subsection{Empirical Review}

\subsubsection{Foreign Studies}

Kinya (2013) used elasticity and buoyancy concept to examine the relationship between tax revenue and economic growth in Kenya from 2002 to 2012. Natural logarithms were used to carry out the elasticity and buoyance estimates. The result was that total tax revenue and economic growth in Kenya had significant relationship.

Saqib, Ali, Riaz, Anwar \& Aslam (2014) researched on the effects of taxation on economic activity in Pakistan from 1973 to 2010. The study provided evidence that taxation effects on real GDP, investment and household consumption expenditure are negative. Thus, the study suggested a reversal action on present level of taxes in Pakistan.

Takumah (2014) employed quarterly time series data to assess the effect of tax revenue and economic growth in Ghana. The data covered a period from 1986 to 2010 and were obtained from World Development Indicators, 2013 edition. The study made use of real gross domestic product (RGDP) as the dependent variable while the explanatory variables include tax revenue, foreign direct investment, consumer price index, gross fixed capital formation, government expenditure and labour force. From the result of the study, tax revenue among others had a positive and significant effect on real GDP. The implication is that when tax revenue is judiciously applied to provision of public services, it boosts the economy of a nation.

Munir and Sultan (2016) investigated the impact of taxes on economic growth of Pakistan using annual time series data that spanned from 1976 to 2014. The study classified taxes in Pakistan into direct and indirect taxes which were used to measure the effect of taxes on real GDP. The reasearchers employed Autoregressive Distribution Lag and the findings established the existence of long-run association between taxes and real GDP of Pakistan. However, all taxes had positive relation with the RGDP in the short run except excise duty which had negative correlation with RGDP. The study hence suggested increase in direct taxes for a better economic growth in Pakistan.

Onakoya, Afintinni \& Ogundajo (2017) carried out a study on the impact of tax revenue on economic growth in Africa from 2004 to 2013. The study made use of 16 selected African countries and employed secondary form of data collected on tax revenues and gross domestic product. The data source was the World Development Indicators. The result of the study showed that tax revenue has positive relationship with economic growth in Africa.

\subsubsection{Studies in Nigeria}

Okafor (2012) investigated the impact of tax revenue generation on Nigeria's economic development from 1981-2007 using Ordinary Least Squares (OLS) regression technique. The result indicated that tax revenue had significant positive correlation with Nigeria's economic development.

Ayuba (2014) used Ordinary Least Squares (OLS) technique to assess the impact of tax revenue on economic growth in Nigeria from 1993 to 2012. The findings revealed that tax revenue has positive impact on economic growth in Nigeria.

Ojong, Ogar and Arikpo (2016) employed Ordinary Least Squares (OLS) method to investigate the impact of tax revenue on economic growth in Nigeria from 1986 to 2010. The findings revealed that tax revenues from direct sources (PIT and CIT) have significant relationship with Nigeria economic growth.

Arowoshegbe, Uniamikogbo and Aigienohuwa (2017) considered the impact of tax revenue on Nigeria's economic growth from 1995 to 2015, using OLS method for estimation, the findings revealed that petroleum profit tax and company income tax exerted significant influence on economic growth more than the indirect taxes.

Okwara and Amori (2017) examined the impact of tax revenue on economic growth in Nigeria using OLS technique and annual time series data covering the period from 1994-2015. The inability of various levels of government to exploit taxing opportunities and rooms for tax avoidance and evasion to thrive in the country were the challenges in Nigerian tax administration. The study used gross domestic product (GDP) as the dependent variable while the explanatory variables were value added tax (VAT) and non-oil revenue. The findings revealed that VAT had negative insignificant influence on GDP while non-oil revenue had significant positive and robust impact on GDP. 
The result confirms the fact that taxation is a revenue source that contributes positively to economic growth of a nation.

\subsection{Gap in Literature}

Owing to dearth of research in the area of the relationship that exist between tax revenue and basic service delivery indicators (SDI) which is now trending among the African nations in collaboration with the World Bank, as the basis for assessment of result oriented government spending by the public, there is need to evaluate the impact of tax revenue on SDI which focuses on education and health care services. Tax revenue has been found a suitable economic growth tool in Nigeria and in other countries (Okafor, 2012; Kinya, 2013; Ayuba, 2014; Takumah, 2014) among others. However, due to the persistent decline in the oil revenue, the Nigerian government is given serious attention to both direct and indirect taxes as the reliable source of filling the gap in government revenue required for proper public service delivery. Based on the above backdrop, this study is channeled to provide an empirical evidence that will serve as a reference point for future researches in this area and to provide policy makers the motivation to boost the drive for tax revenue necessary to enhance government proper service delivery. The study also has evidences that encourage efficient tax administration while providing proof for complete eradication of tax evasions that reduce government's chances of having more revenues to meet the needs of the public.

\section{Methodology}

The ex-post facto research design was preferred in this study because the secondary form of data employed were not under the control of the researchers but have already been captured in the archive of CBN Statistical Bulletin, 2017 edition. The tax revenue (TRV) used here as the independent variable excludes petroleum profit tax (PPT) but includes all non-oil revenues in Nigeria comprising personal income tax, companies income tax, capital gains tax, withholding tax and all form of indirect taxes (Accounting Technicians Scheme West African (ATSWA), 2009). Thus, government spending on education (EDU) and health care services (HLT) are the dependent variables. The data for all the variables (both dependent and independent) were obtained from Central Bank of Nigeria Statistical Bulletin, 2017 edition and covered a period from 1981-2017. Simple regression technique was employed for analysis with the use of e-views version 9. The rejection criterion for testing of null hypotheses is at $5 \%$ level of significance, the p-value of individual result above 5\% significance level is accepted and is rejected if otherwise.

Based on Koutsoyiannis (1977) model which states that economic theory does not specify the practical form of any relationship.

Guided by the theory above, the model considered suitable for this study is specified below:

$$
\mathrm{PSD}=\mathrm{f}(\mathrm{TRV})
$$

Where $=$ PSD $=$ Public Service Delivery; TRV $=$ Tax Revenue .

Hypothesis 1

$$
\text { LOGEDU }=\mathrm{f}(\text { LOGTRV })
$$

Where $=$ LOGEDU $=$ Education Services; LOGTRV $=$ Tax Revenue.

Expressed in its explicit form as follows:

$$
Y=\propto+\beta_{1} X_{1}+\mu
$$

Where $=\mathrm{Y}=$ Education Services; $\alpha=$ Constant; $\beta=$ coefficient of the regression Equation; $\mathrm{X}=$ Tax Revenues; $\mu=$ error term.

Hypothesis 2

$$
\text { LOGHLT }=\mathrm{f}(\text { LOGTRV) }
$$

Where $=$ LOGHLT $=$ Health Care Services LOGTRV $=$ Tax Revenue.

Expressed in its explicit form as follows:

$$
\mathrm{Y}=\propto+\beta_{1} \mathrm{X}_{1}+\mu
$$

Where $=\mathrm{Y}=$ Health Care Services; $\propto=$ Constant; $\beta=$ coefficient of the regression Equation; $\mathrm{X}=$ Tax Revenues; $\mu=$ error term. 


\subsection{A Prior Expectation}

The A prior expectation is that tax revenue should be greater than zero implying positive contribution to public service delivery in the area of education and health care services.

\section{Results and Findings}

Hypothesis 1: Tax revenue does not have significant impact on education in Nigeria.

Table 1. Tax revenue and education regression results

\begin{tabular}{|c|c|c|c|c|}
\hline \multicolumn{5}{|c|}{ Dependent Variable: LOGEDU } \\
\hline \multicolumn{5}{|c|}{ Method: Least Squares } \\
\hline \multicolumn{5}{|c|}{ Date: $12 / 28 / 18$ Time: 06:07 } \\
\hline \multicolumn{5}{|l|}{ Sample: 19812017} \\
\hline \multicolumn{5}{|c|}{ Included observations: 37} \\
\hline Variable & Coefficient & Std. Error & $\mathrm{t}$-Statistic & Prob. \\
\hline LOGTRV & 1.099597 & 0.039261 & 28.00762 & 0.0000 \\
\hline$\overline{\mathrm{C}}$ & -2.839724 & 0.218959 & -12.96920 & 0.0000 \\
\hline R-squared & 0.957287 & Mean dependent var & & 2.686093 \\
\hline Adjusted R-squared & 0.956067 & S.D. dependent var & & 2.755725 \\
\hline S.E. of regression & 0.577606 & Akaike info criterion & & 1.792690 \\
\hline Sum squared resid & 11.67702 & Schwarz criterion & & 1.879767 \\
\hline Log likelihood & -31.16477 & Hannan-Quinn criter. & & 1.823389 \\
\hline F-statistic & 784.4267 & Durbin-Watson stat & & 2.163439 \\
\hline
\end{tabular}

Source: Authors' Computation, 2019.

The regression results on Table 1 show the value of $\mathrm{R}$ to be $97.8 \%$ (square root of $\mathrm{R}$-squared), this is an indication that tax revenue has a strong and positive relationship with provision of education in Nigeria. The result has also proved that tax revenue has been utilized to a great extent to provide education in the country. The value of R-squared is $95.7 \%$ which implies the extent to which tax revenue (TRV) explains the variations in education (EDU). In other words, it is only $4.3 \%$ that is attributable to variables outside the model. The regression result shows that the value of F-statistic is 784.43 with the p-value of $0.000<0.05$; this result indicates that the model is a good fit and statistically significant. The Durbin-Watson is approximately 2 which shows absence of autocorrelation. $\mathrm{The}^{\mathrm{Ho}} \mathrm{Ho}_{1}$ testing is based on the outcome of the t-statistics which is 28.007 while the p-value is $0.000<0.05$; this means tax revenue has a robust and significant positive impact on education. Therefore, $\mathrm{Ho}_{1}$ which states that tax revenue does not have significant impact on education is hereby rejected and the alternative which suggests otherwise accepted.

This result is in agreement with the findings of (Okafor, 2012; Kinya, 2013; Ayuba, 2014; Takumah, 2014) among others who found positive relationship between tax revenue and economic growth in their different studies.

Hypothesis 2: Tax revenue does not significantly influence health care services in Nigeria.

Table 2. Tax revenue and health services regression results

Dependent Variable: LOGHLT

Method: Least Squares

Date: 12/28/18 Time: 06:13

Sample (adjusted): 19812000 


\begin{tabular}{lllll}
\hline Included observations: 20 after adjustments & & \\
\hline Variable & Coefficient & Std. Error & t-Statistic & Prob. \\
\hline LOGTRV & 1.581812 & 0.125527 & 12.60136 & 0.0000 \\
\hline C & -3.831028 & 0.435522 & -8.796399 & 0.0000 \\
\hline R-squared & 0.898187 & Mean dependent var & 1.079853 \\
\hline Adjusted R-squared & 0.892530 & S.D. dependent var & 2.652463 \\
\hline S.E. of regression & 0.869545 & Akaike info criterion & 2.652946 \\
\hline Sum squared resid & 13.60996 & Schwarz criterion & 2.752520 \\
\hline Log likelihood & -24.52946 & Hannan-Quinn criter. & 2.672384 \\
\hline F-statistic & 158.7942 & Durbin-Watson stat & 1.983616 \\
\hline Prob(F-statistic) & 0.000000 & &
\end{tabular}

Source: Authors' Computation, 2019.

The regression results on Table 2 reveal that tax revenue has a strong positive relationship with the provision of health care services in Nigeria. The value of $\mathrm{R}$ is $94.8 \%$, which shows the existence of a very robust correlation between tax revenue and health care services in Nigeria. The R-squared of $89.8 \%$ is equally very strong. It shows that tax revenue explains about $89.8 \%$ of the changes in health care services while the remaining $10.2 \%$ is accountable by other factors not included in the model. F-statistic is 158.7942 and has the p-value of $0.000<0.05$. Therefore, the result is statistically significant and the model is appropriate for the study. The Durbin-Watson is approximately 2; showing absence of autocorrelation. Testing of $\mathrm{Ho}_{2}$ is based on the result of the t-statistics which is 12.60136 with the p-value of $0.000<0.05$ level of significance. Thus, $\mathrm{Ho}_{2}$ is hereby declined while the alternative suggestion is established. This result agrees with the findings of other Scholars such as (Okafor, 2012; Kinya, 2013; Ayuba, 2014; Takumah, 2014) among others.

\section{Conclusion and Recommendations}

Public service delivery indicators focused on education and health care services in the African countries is a move in the right direction. It takes a healthy nation to make wealth and education is key to economic growth of every nation. The result of this study met a prior expectation and shows that tax revenue has a strong positive relationship with provision of health care services and education in Nigeria. These findings have given credence to government's effort to exploit all revenue sources through taxation in the country for proper public service delivery. This will in a way prove the right application of benefit received theory in the country. However, the study has provided the following recommendations deemed necessary for more improvement in tax revenue collection and public service delivery.

The study encourages Federal Inland Revenue Service (FIRS) to devise better strategies to prevent tax evasion which has over the years led to decrease in government revenue while ensuring that all perpetrators are duly punished. All government efforts to generate revenue for adequate public service delivery should be supported by non-government organizations, firms, individuals and all stake holders in the country.

Tax revenue should be properly utilized by the government to provide a good educational system in Nigeria. The government should always consider provision of education as a very important service that requires priority attention. Education reforms the mind and curtails crime in a country to a reasonable extent. Education includes skill acquisitions and entrepreneurship development programmes. In addition, regular payment of academic staff salaries and other allowances should not be overlooked to avoid frequent nationwide strike of academic workers. The government should endeavor to restrict academic workers strike in the country because too much of it exposes the young ones to crime.

The study also recommends maintenance culture in the health sector. Most government health centers and hospitals (including the facilities) are not in good condition. The government should focus attention to these health care providers in the country and ensure that the facilities they work with are properly maintained. This will to a great extent minimize the level of health care services being sought for outside the country by the citizens. 


\section{References}

Ahuja, H. L. (2012). Modern Economics (16th ed.). S. Chand \& Company Ltd.

Anderfuhren-Biget, S., Varone, F., \& Giauque, D. (2014). Policy environment and public service Motivation. Public Administration, 92(4), 807-825. https://doi.org/10.1111/padm.12026

Anyaduba, J. O. (2004). Partnership taxation in Nigeria. ICAN Student Journal, 9(2), 15-17.

Anyanfo, A. M. O. (1996). Public Finance in a Developing Economy: The Nigerian Case. Department of Banking and Finance, University of Nigeria, Enugu Campus, Enugu.

Appah, E. (2010). The problems of tax planning and administration in Nigeria: The Federal and State Governments experience. International Journal of Labour and Organizational Psychology, 4, 1-14.

Arowoshegbe, A. O., Uniamikogbo, E., \& Aigienohuwa, O. O. (2017). Tax revenue and economic Growth in Nigeria. Scholars Journal of Economics, Business and Management, 4(10), 696-702.

ATSWA. (2009). Public Sector Accounting (2nd ed.). Accounting Technicians Scheme (West Africa). ABWA Publishers.

Ayuba, A. J. (2014). Impact of non-oil tax revenue on economic growth: The Nigerian Perspective. International Journal of Finance and Accounting, 3(5), 303-309.

Bhartia, H. L. (2009). Public Finance (14th ed.). Vikas Publishing House PVT Ltd., New Delhi.

Brautigam, D. (2008). Taxation and governance in Africa. Retrieved from http://www.aei.org/publication/taxation-and-governance-in-africa

Central Bank of Nigeria. (2017). CBN Statistical Bulletin (2017 ed.).

Chigbu, E. E., Akujuobi, L. E., \& Appah, E. (2012). An empirical study on the causality between Economic growth and taxation in Nigeria. Current Research Journal of Economic Theory, 4(2), 29-38.

Chokri, T., Anis, E., Ali, B., \& Khali, M. (2017). Optimal Taxation and Economic Growth in Tunisia: short and long run co-integration analysis. HAL archives Ouvertes. Retrieved December 11, 2018, from https://hal.archives-ouvertes.fr/hal-01541131

Constitution of the Federal Republic of Nigeria. (1999). Second Schedule: Part 1: Exclusive List. Part 11: Concurrent Legislative List. Part 111 Supplemental and Interpretation.

Dandago, K. I., \& Alabede, J. O. (2001). Taxation and tax administration in Nigeria. Kano: Triumph Publishing Company Limited.

Engen, E. M., \& Skinner, J. (1992). Fiscal policy and economic growth. Journal of Development Economics, 39(1), 5-30.

Frost \& Sullivan. (2012). Public Service Delivery - Gets - rights, challenges and successes. Retrieved December 23, 2018, from http://www.frost.com

Harberger, A. C. (1962). The incidence of the corporation income tax. Journal of Political Economy, 70(3), $215-240$. https://doi.org/10.1086/258636

Herberger, A. C. (1966). Efficiency effects of taxes on income from capital. In M. K. Detroit (Ed.), Effects of Corporation Income Tax. Wayne State University Press.

IGI Global. (2018). What is public service delivery?. Retrieved December 22, 2018, from https://www.igi-global.com/dictionary/public-service-delivery/33101

Ihenyen, C. J., \& Mieseigha, E. G. (2014). Taxation as an instrument of economic growth: The Nigerian perspective. Information and Knowledge Management, 4(12), 49-53.

Kinya, J. D. (2013). The relationship between tax revenue and economic growth in Kenya. MBA Research project submitted to School of Business, University of Nairobi.

Koutsoyainnis, A. (1977). Theory of Econometric. Humpshire Macmillan Education Ltd, London. https://doi.org/10.1007/978-1-349-09546-9

Lindahl, E. (1919). Just Taxation - A positive solution. In E. Henderson (Translated), R. A. Musgrave, and A. T. Peacock (Eds.), Classics in the Theory of Public Finance. Macmillan. 
McGregor, E. B. Jr., Campbell, A. K., Macy, J. W., \& Cleveland, H. (1982). Symposium: The public Service as Institution. Public Administration Review Washington, 42(4), 304-320. https://doi.org/10.2307/975969

Munir, K., \& Sultan, M. (2016). Are some taxes better for growth in Pakistan? A Time Series Analysis. MPRA. Retrieved from https://mpra.ub.uni-muenchen.de/688281/

Musgrave, R. A. (2006). Public Finance and three branch model. In A. F. Ottve, \& R. J. Cebula (Eds.), The Elgar Companion to Public Economics - empirical public economics. Cheltenham: Edward Elgar. https://doi.org/10.4337/9781845424558.00012

Nzotta, S. M. (2007). Tax evasion problems in Nigeria: A critizue. Nigerian Accountant, 40(2), 40-43.

Ojong, C. M., Ogar, A., \& Arikpo, O. F. (2016). The impact of tax revenue on economic growth: Evidence from Nigeria. IOSR Journal of Economics and Finance, 7(1), 32-38.

Okafor, R. G. (2012). Tax revenue generation and Nigerian economic development. European Journal of Business and Management, 4(19), 49-56.

Okwara, C. C., \& Amori, O. C. (2017). Impact of tax revenue on economic growth in Nigeria. International Journal of Advanced Scientific Research, 2(2), 90-102.

Omodero, C. O., Okafor, M. C., Azubike, J. U., \& Ekwe, M. C. (2016). Re-engineering VAT Administration in Nigeria for economic development. European Journal of Accounting, Auditing and Finance Research, 4(7), 6-22.

Onakoya, A. B., Afintinni, O. I., \& Ogundajo, G. O. (2016). Taxation revenue and economic growth in Africa. Journal of Accounting and Taxation, 9(2), 11-12. https://doi.org/10.5897/JAT2016.0236

Open Government Partnership. (2018). Public Service Delivery. Retrieved on December 23, 2018, from https://www.opengovpartnership.org

Piana, V. (2003). Tax revenue. Economic Web Institute. Retrieved on December 24, 2018, from http://economicswebinstitute.org/glossary/tax

Ray, T. (2007). Shared Services in Local Government, Improving Service Delivery. Gower Publishing Company, USA.

Ringold, D., Alaka, H., Koziol, M., \& Santhosh, S. (2012). Citizens and Service Delivery: Assessing the use of social accountability approaches in human development. Washington D.C.: World Bank.

Saqib, S., Ali, T., Riaz, M. F., Anwar, S., \& Aslam, A. (2014). Taxation effects on economic Activity in Pakistan. Journal of Finance and Economics, 2(6), 215-219. https://doi.org/10.12691/jfe-2-6-3

Takumah, W. (2014). Tax revenue and economic growth in Ghana: A co-integration Approach. Munich Personal RePec Archive. Retrieved from http://mpra.ub.uni-muenchen-de/58532/

Wicksell, K. (1896). Finanztheoretische Untersuchungen. Gustav Fisher: Jena.

World Bank. (2017). Service Delivery Indicators. Retrieved December 23, 2018, from http://data.worldbank.org/ 